\title{
Polymeric Pseudo-Liquid Membranes from Polymethacrylate Derivative Bearing Oligodimethylsiloxane Unit
}

\author{
Hiroki Tsujimoto and Masakazu Yoshikawa*
}

\author{
Department of Biomolecular Engineering, Kyoto Institute of Technology, Matsugasaki, Kyoto 606-8585, \\ Japan
}

\begin{abstract}
Novel liquid membrane system, which is named polymeric pseudo-liquid membrane was constructed from polymethacrylate derivative bearing oligodimethylsiloxane (PDMSMA), showing rubbery state under operating conditions, as a membrane matrix. In the present study, dibenzo-18-crown-6 (DB18C6), dibenzo-21-crown-7 (DB21C7) or O-allyl- $\mathrm{N}$-(9-anthracenylmethyl)cinchonidinium bromide (AMCC) was adopted as a carrier for $\mathrm{KCl}$ transport, $\mathrm{CsCl}$ transport or optical resolution of racemic mixture of phenylglycine (Phegly), respectively. The results of $\mathrm{KCl}$ and $\mathrm{CsCl}$ transports revealed that the membrane transport was attained by carrier-diffusion mechanism like conventional liquid membranes. The present study led the conclusion that PDMSMA can be applicable not only to membrane transport of alkali metal ions, such as $\mathrm{K}^{+}$and $\mathrm{Cs}^{+}$, but also to chiral separation.
\end{abstract}

Keywords: Chiral separation, Crown ether, Liquid membrane, Optical resolution, Polymeric pseudo-liquid membrane.

\section{INTRODUCTION}

Membrane separation has been perceived as an environmentally benign and an economically promising separation technology among separation technologies, such as distillation, crystallization and so on [1-5]. Membranes have been already applied to various areas, such as seawater desalination by reverse osmosis (RO), ultrapure water production by nanofiltration (NF), separation or concentration of colloidal particles and macromolecules by ultafiltration (UF), reduction of water turbidity by microfiltration (MF) and elecrtodialysis (ED) by ion-exchange membranes, removal and recovery of gases, hemofiltration, hemodiafiltration, hemodialysis and so on. So far, membranes have been applied to separation by using the difference in dimension between the target molecule and others. When the difference in dimension between target molecule and others becomes narrower and finally a given mixtures show similar or same dimensions, such as constitutional isomers or enantiomers, will not be separated well by membrane separation techniques enumerated above. In order to separate mixtures showing similar or same dimension, a given membrane has to discriminate the target molecule by recognizing the difference in shape and the alignment of functional moiety (substituent). To this end, it is necessary to introduce molecular recognition sites or molecular recognition materials into a given separation membrane.

*Address correspondence to this author at the Department of Biomolecular Engineering, Kyoto Institute of Technology, Matsugasaki, Kyoto 606-8585, Japan; Tel: +81-75-724-7816; Fax: +81-75-724-7816;

E-mail: masakazuyoshikawa@yahoo.com
Synthetic membrane with molecular recognition ability is divided into a couple of categories, such as "mobile carrier membrane (liquid membrane)" and "fixed carrier membrane". In the former membrane, there can be found a given carrier, showing molecular recognition ability toward the target molecule, in a membrane matrix of a liquid material. In the latter, a molecular recognition site or a molecular recognition material is attached to polymeric material via covalent bond. The permselectivity of liquid membrane is thought to reflect molecular recognition ability of carrier impregnated into the membrane, while that of fixed carrier membrane is often fell down by the membrane swelling. In addition, it is much easier to construct a liquid membrane, since a liquid membrane is constructed by just dissolving a carrier into a membrane matrix of solvent.

However, liquid membrane has not been applied in practice. This is due to the following drawbacks in a liquid membrane [6-11]; (1) short life-time (lack of longterm stabilization), (2) leakage of solvent consisting of membrane matrix (liquid) and (3) washing out of carrier and/or target molecule/carrier complex. Overcoming of the drawbacks enumerated above will make a liquid membrane one of promising membrane separation systems for the separation of mixtures with similar or same molecular dimension, such as constitutional isomers and enantiomers.

Up to now, six types of liquid membrane has been proposed as durable liquid membranes, such as (1) polymer liquid crystal composite membranes [12, 13]; polymer inclusion membranes (PIMs) [14-22]; 
organogel membranes [23, 24]; (4) stabilization of supported liquid membranes [25, 26]; (5) liquid membranes based on ionic liquids [27-29]; and (6) polymeric pseudo-liquid membranes (PPLMs) [30-37].

Polymeric pseudo-liquid membrane (PPLM) has been studied based on the knowledge of polymer science, especially, polymer physics. PPLM is a liquid membrane consisting of polymeric material with a rubbery state and a carrier. In PPLM, a polymeric material works as a membrane matrix retaining a carrier and a durable barrier, separating source and receiving phases. From above, PPLM is a different membrane system from a supported polymeric liquid membrane [38-41]. A supported polymeric liquid membrane is a microporous hydrophobic membrane, of which pore is loaded with a polymeric (oligomeric) liquid exhibiting an affinity toward organic compounds of interest.

In the studies on PPLMs, polymeric materials, which show rubbery state and fluidity, were chosen as a membrane matrix dissolving a carrier and were working as a barrier separating source and receiving phases. So far, poly(2-ethylhexyl methacrylate) (P2EHMA), with glass transition temperature $\left(T_{\mathrm{g}}\right)$ of $-14.3{ }^{\circ} \mathrm{C}$ [33], poly(2-ethylhexyl acrylate) (P2EHA) with $T_{\mathrm{g}}$ of $-60.5^{\circ} \mathrm{C}$ [34], poly(dodecyl methacrylate) (PC12MA) with $T_{g}$ of $66.3^{\circ} \mathrm{C}$ [35], poly ( $\mathrm{N}$-oleylacrylamide) (PC18AAm) with $T_{\mathrm{g}}$ of $-85.0{ }^{\circ} \mathrm{C}$ [37] and poly(octadecyl methacrylate) (PC18MA) with $T_{\mathrm{g}}$ of $-101.2{ }^{\circ} \mathrm{C}[36,42]$ were adopted as membrane matrices for PPLMs.

Even though PPLM consisted of a rubbery polymer, which showed fluidity, as a membrane matrix, diffusivities of carrier and carrier/target molecule complex in it is lower than those in a usual liquid membrane, which consisted of organic liquid, such as chloroform etc. and a carrier. It is required to construct PPLM adopting a polymeric material, of which $T_{\mathrm{g}}$ is lower than those previously studied [33-37] so that the novel PPLM can show a higher flux value than those observed previously. To this end, in the present study, polymethacrylate derivative bearing oligodimethylsiloxane (PDMSMA), of which $T_{\mathrm{g}}$ is expected to be around $-120{ }^{\circ} \mathrm{C}$, was adopted as a candidate membrane matrix for PPLM. Herein, transport of $\mathrm{KCl}$ by dibenzo-18-crown-6 (DB18C6), that of $\mathrm{CsCl}$ by dibenzo-21-crown-7 (DB21C7) and chiral separation of racemic mixture of phenylglycine (Phegly) by $\mathrm{O}-$ allyl- $\mathrm{N}$ (9-anthracenylmethyl)cinchonidinium bromide (AAMC) were studied.

\section{EXPERIMENTAL}

\subsection{Materials}

Methacrylate derivative bearing oligodimethylsiloxane (DMSMA), of which average degree of constitutional repeating unit of dimethylsiloxane was determined to be 2.5 by ${ }^{1} \mathrm{H}$ NMR, was kindly provided by Shin-Etsu Chemical Co., Ltd. (Tokyo, Japan). The chemical structure of DMSMA can be seen in Figure 1. 2,2'-Azobis(2-methylpropionitrile) (AIBN) [45] and toluene [46] were purified by conventional methods. Copper(I) chloride, $N, N, N^{\prime}, N^{\prime \prime}, N^{\prime \prime}$-pentamethyldiethylenetriamine (PMDETA), ethyl 2-bromo-2-methylpropanoate (EBMP), methanol, dibenzo-18-crown-6 (DB18C6), KCl, dibenzo-21-crown-7 (DB21C7), CsCl, $\mathrm{O}$-allyl- $\mathrm{N}$-(9-anthracenylmethyl)cinchonidinium bromide (AAMC), D-phenylglycine (D-Phegly) and Lphenylglycine (L-Phegly) were obtained from commercial sources and used without further purifications. Water purified with an ultrapure water system (Simpli Lab, Millipores S. A., Molsheim, France) was used.

\subsection{Polymerization of DMSMA}

Prior to polymerization, the inhibitor in DMSMA was removed by passing the monomer through an alumina column.

Conventional radical polymerization of DMSMA initiated by AIBN was carried out as follows; $8.007 \mathrm{~g}$ $\left(1.74 \times 10^{-2} \mathrm{~mol}\right)$ of DMSMA and $15.4 \mathrm{mg}\left(9.38 \times 10^{-5}\right.$ $\mathrm{mol}$ ) of AIBN and $48 \mathrm{~cm}^{3}$ of toluene were degassed by three freeze-pump-thaw cycles and sealed off below $1.3 \times 10^{-2} \mathrm{~Pa}\left(1.0 \times 10^{-4} \mathrm{mmHg}\right)$. The sealed ampoule was shaken in the water bath at a constant temperature of $45{ }^{\circ} \mathrm{C}$ for $145 \mathrm{~h}$. The polymerization solution was poured into methanol at around $-90{ }^{\circ} \mathrm{C}$ and then the obtained precipitate was dried in vacuo at ambient temperature for 5 days. $6.32 \mathrm{~g}(78.9 \%)$ of PDMSMA was obtained.

DMSMA was also polymerized by atom transfer radical polymerization (ATRP) $[47,48]$ so that PDMSMA with the prescribed degree of polymerization (molecular weight) could be obtained. Polymerization scheme is shown in Figure 1. ATRP of DMSMA was carried out as follows: $\mathrm{CuCl}$ was degassed by vacuum followed by nitrogen backfill three times. The prescribed amounts of DMSMA, EBMP and ligand (PMDETA) which had been degassed by three freezepump-thaw cycles and then back-filled with nitrogen were added by syringe and placed in a thermostated oil 


\section{DMSMA}<smiles>C/C=C(/C)C(=O)OCCC[Si](C)(C)O[Si](C)(C)O[Si](C)(C)C</smiles>

\section{PDMSMA}<smiles>CCOC(=O)C(C)C=CC(C)(C)C(=O)OCC</smiles><smiles>CCC[Si](C)(C)O[Si](C)(C)O[Si](C)(C)C</smiles>

at $70{ }^{\circ} \mathrm{C}$ for $12 \mathrm{~h}$

CUCI/EBMP PMDETA<smiles>CCOC(=O)C(C)(C)Br</smiles>

EBMP<smiles>CN(C)CCN(C)CCN(C)C</smiles>

PMDETA

Figure 1: Scheme for synthesis of PDMSMA by ATRP.

bath at $70{ }^{\circ} \mathrm{C}$ for $12 \mathrm{~h}$. The polymerization solution was dissolved into $\mathrm{CHCl}_{3}$ and passed over an alumina (activated neutral) column to remove the catalyst. The solution was poured into methanol at around $-90{ }^{\circ} \mathrm{C}$ and then the obtained precipitate was dried in vacuo at ambient temperature for 5 days.

\subsection{Characterization of PDMSMA}

Gel permeation chromatography (GPC) was performed on a JASCO liquid chromatography system composed of a PU-2089 HPLC pump and an 860-CO column oven (operated at $35{ }^{\circ} \mathrm{C}$ ) equipped with a JASCO 870-UV (JASCO Co., Hachioji, Japan) and a Shodex RI-101 RI detector (Showa Denko K. K., Tokyo, Japan). Polystyrene standard (Tosoh Co., Tokyo, Japan) were used for calibration and THF as eluent at a flow rate of $1.0 \mathrm{~cm}^{3} \mathrm{~min}^{-1}$.

Differential scanning calorimetry (DSC) measurements were performed with Shimadzu DSC-60 (Shimadzu Co., Kyoto, Japan). The heating rate was fixed to be $10{ }^{\circ} \mathrm{C} \mathrm{min}{ }^{-1}$ and the sample was purged with nitrogen at a flow rate of $50 \mathrm{~cm}^{3} \mathrm{~min}^{-1}$.

\subsection{Preparation or Polymeric Pseudo-Liquid Membranes}

Polymeric pseudo-liquid membranes were prepared as follows; $100 \mathrm{mg}$ of PDMSMA and the prescribed amount of DB18C6, of which amount was $2.50 \mathrm{mg}$, $5.00 \mathrm{mg}$ or $7.50 \mathrm{mg}$, were dissolved in $1.0 \mathrm{~cm}^{3}$ of $\mathrm{CHCl}_{3}$. In the case that DB21C7 was used as a carrier instead of DB18C6, $100 \mathrm{mg}$ of PDMSMA and $2.50 \mathrm{mg}$ of DB21C7 were dissolved in $1.0 \mathrm{~cm}^{3}$ of $\mathrm{CHCl}_{3}$. The polymer solution was poured into a flat-laboratory-dish (48 $\mathrm{mm}$ diameter), followed by immersing a PTFE membrane filter (Omnipore Membrane Filter (Merck Millipore, Bellerica, MA, USA); diameter $47 \mathrm{~mm}$; pore radius $0.10 \mu \mathrm{m}$; porosity 0.80 ; thickness, $80 \mu \mathrm{m}$ ) into the cast solution. Then the flat-laboratory-dish was evacuated in a desiccator so that the cast solution could thoroughly penetrate into pores in the PTFE membrane filter. The solvent was allowed to evaporate at $25^{\circ} \mathrm{C}$ for $5 \mathrm{~h}$ and then additionally at $60^{\circ} \mathrm{C}$ for $24 \mathrm{~h}$.

Control membrane was prepared as follows; about $100 \mathrm{mg}$ of PDMSMA was dissolved in $1.0 \mathrm{~cm}^{3}$ of $\mathrm{CHCl}_{3}$. Control membrane for PPLM was constructed from the solution thus prepared as described above. 
PPLM for chiral separation of Phegly was prepared as described above. Instead of carrier for alkali metal ions, $2.50 \mathrm{mg}$ of $\mathrm{O}$-allyl- $\mathrm{N}$-(9-anthracenylmethyl) cinchonidinium bromide (AAMC) was used as a carrier for chiral separation of racemic mixture of Phegly.

\subsection{Transport of Alkali Metal Salts}

Transport of alkali metal salt, such as $\mathrm{KCl}$ and $\mathrm{CsCl}$, was studied using apparatus schematically shown in Figure 2. The PTFE membrane filter impregnated with membrane components, such as PDMSMA and carrier or just PDMSMA, was secured tightly with Parafilm between two chambers of permeation cell. The thickness of the PTFE filter, $80 \mu \mathrm{m}$, was adopted as membrane thickness for the present study. In the present study, the membrane area for PTFE membrane filter was $3.0 \mathrm{~cm}^{2}$; the effective membrane area was determined to be $2.4 \mathrm{~cm}^{2}$. The volume of each chamber was $40.0 \mathrm{~cm}^{3}$. A $1.0 \times 10^{-4} \mathrm{~mol} \mathrm{~cm}^{-3}$ of $\mathrm{KCl}$ or $\mathrm{CsCl}$ aqueous solution was placed in the lefthand side chamber (L-side) and deinonized water in the right-hand side chamber (R-side). Transport experiments of $\mathrm{KCl}$ were carried out at $40{ }^{\circ} \mathrm{C}(313 \mathrm{~K})$, $50{ }^{\circ} \mathrm{C}(323 \mathrm{~K})$ and $60{ }^{\circ} \mathrm{C}(333 \mathrm{~K})$, respectively. That of $\mathrm{CsCl}$ was studied at $60{ }^{\circ} \mathrm{C}$. Aqueous solutions in both chambers were stirred by magnetic stirrers. The revolution rate of magnetic stirrer was kept apparently constant as possible, though that could not be specified in the present study. Concentration of $\mathrm{KCl}$ or $\mathrm{CsCl}$ in the permeate side (R-side) was determined by conductometric analysis by using Portable Kohlrausch Bridge TYPR BF-62A (Shimadzu Rika Instruments Co. Ltd., Kyoto, Japan) and CO-1305 oscilloscope (Kenwood Co., Hachioji, Tokyo), of which schematic diagram is shown in Figure 2.

\subsection{Transport of Racemic Mixture of Phegly}

Aqueous solution of racemic Phegly was placed in the left-hand side chamber (L-ide) and aqueous solution in the right-hand side chamber (R-side). Each concentration of racemic Phegly was fixed to be $1.0 \mathrm{x}$ $10^{-6} \mathrm{~mol} \mathrm{~cm}^{-3}$. Transport experiments were carried out at $40{ }^{\circ} \mathrm{C}(313 \mathrm{~K})$. The $\mathrm{pH}$ condition of the source phase (L-side) was kept to be 11 by $\mathrm{Na}_{2} \mathrm{HPO}_{4} / \mathrm{NaOH}$ and that of receiving phase was maintained at $\mathrm{pH} 3$ by $\mathrm{H}_{3} \mathrm{PO}_{4} / \mathrm{NaH}_{2} \mathrm{PO}_{5}$.

The amounts of D-Phegly and L-Phegyl transported through the PPLM were determined by liquid chromatography (LC) [JASCO PU-2080, equipped with a UV detector (JASCO UV-2075) (JASCO Co., Hachioji, Japan)], using a CHIRALPAK MA(+) column [50 x $4.6 \mathrm{~mm}$ (i.d.)] (Daicel Co., Osaka, Japan) and aqueous copper sulfate as an eluent.

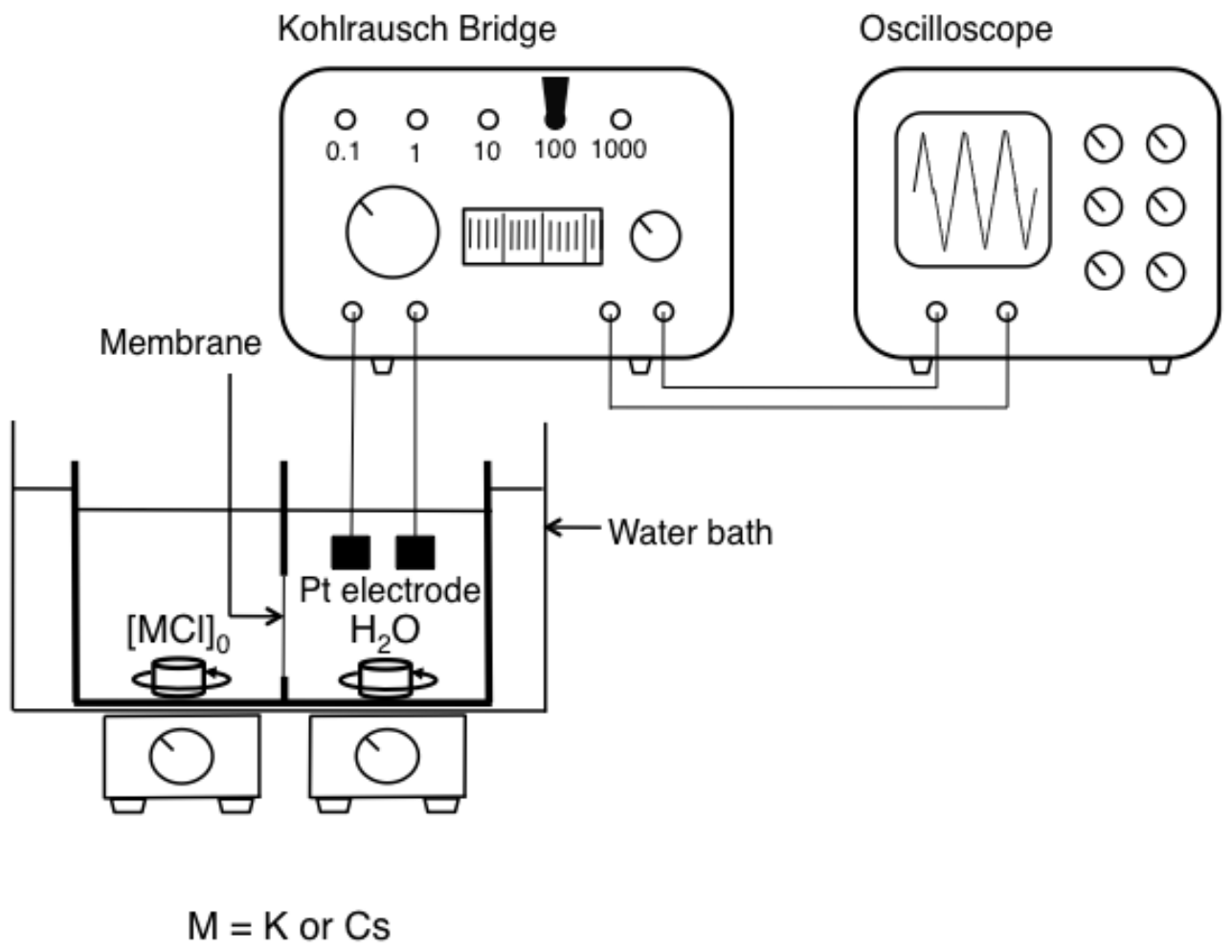

Figure 2: Schematic representation of the setup for metal ion transport experiment. 
Table 1: Conditions and Results of the Syntheses of PDMSMA

\begin{tabular}{|c|c|c|c|c|c|c|c|c|c|c|c|c|c|c|c|c|}
\hline & \multirow{2}{*}{\multicolumn{2}{|c|}{ DMSMA g (mol) }} & \multirow{2}{*}{\multicolumn{2}{|c|}{$\begin{array}{l}\text { AIBN mg } \\
(\mathrm{mol})\end{array}$}} & \multirow{2}{*}{\multicolumn{2}{|c|}{$\mathrm{CuCl} \mathrm{mg} \mathrm{(mol)}$}} & \multirow{2}{*}{\multicolumn{2}{|c|}{$\begin{array}{l}\text { EBMP mg } \\
(\mathrm{mol})\end{array}$}} & \multirow{2}{*}{\multicolumn{2}{|c|}{$\begin{array}{l}\text { PMDETA mg } \\
(\mathrm{mol})\end{array}$}} & \multirow{2}{*}{$\begin{array}{l}\text { Solvent } \\
\mathrm{cm}^{3}\end{array}$} & \multicolumn{2}{|c|}{ Yield } & \multirow{2}{*}{$\begin{array}{c}10^{-3} \\
M_{\mathrm{n}}\end{array}$} & \multirow{2}{*}{$M_{\mathrm{w}} / M_{\mathrm{n}}$} & \multirow{2}{*}{$T_{\mathrm{g}}{ }^{\circ} \mathrm{C}$} \\
\hline & & & & & & & & & & & & $a$ & $\%$ & & & \\
\hline $\begin{array}{c}\text { PDMSMA- } \\
13^{\mathrm{a}}\end{array}$ & 10.004 & & - & & 339.5 & $\begin{array}{c}(3.43 x \\
\left.10^{-3}\right)\end{array}$ & 222.9 & $\begin{array}{c}(1.14 \mathrm{x} \\
\left.10^{-3}\right)\end{array}$ & 594.2 & $\begin{array}{c}(3.43 x \\
\left.10^{-3}\right)\end{array}$ & - & 4.85 & 48.5 & 12.7 & 1.3 & -121.4 \\
\hline $\begin{array}{l}\text { PDMSMA- } \\
27^{\mathrm{a}}\end{array}$ & 10.024 & & - & & 119.1 & $\begin{array}{c}(1.20 x \\
\left.10^{-3}\right)\end{array}$ & 76.7 & $\begin{array}{c}(3.93 x \\
\left.10^{-4}\right)\end{array}$ & 206.9 & $\begin{array}{c}(1.19 x \\
\left.10^{-3}\right)\end{array}$ & - & 6.03 & 60.2 & 26.5 & 1.4 & -120.8 \\
\hline $\begin{array}{c}\text { PDMSMA- } \\
168^{\mathrm{b}}\end{array}$ & 8.007 & $\begin{array}{c}(1.74 \mathrm{x} \\
\left.10^{-2}\right)\end{array}$ & 15.4 & $\begin{array}{c}(9.38 \mathrm{x} \\
\left.10^{-5}\right)\end{array}$ & - & & - & & - & & $48^{c}$ & 6.32 & 78.9 & 168.0 & 2.5 & -121.1 \\
\hline
\end{tabular}

${ }^{\text {aP }}$ olymerization temp., $70^{\circ} \mathrm{C}$; polymerization time, $12 \mathrm{~h}$.

${ }^{\mathrm{b}}$ Polymerization temp., $45^{\circ} \mathrm{C}$; polymerization time, $145 \mathrm{~h}$.

${ }^{\mathrm{c}}$ Toluene.

The permselectivity $\alpha_{\mathrm{L} / \mathrm{D}}$ is defined as the flux ratio, $J_{L} / J_{D}$, divided by the concentration ratio [L-Phegly]/[DPhegly]

$\alpha_{\mathrm{L} / \mathrm{D}}=\left(J_{\mathrm{L}} / J_{\mathrm{D}}\right) /([\mathrm{L}-$ Phegly $] /[\mathrm{D}-$ Phegly $])$

\section{RESULTS AND DISCUSSION}

\subsection{Characterization of PDMSMA}

Conditions and results of polymerization are summarized in Table 1. As expected from the fact that the polymerization initiated by EBMP was controlled/living radical polymerization [47, 48], polydispersity indices for PDMSMA prepared by ATRP were narrower than that initiated by AIBN.

The glass transition temperatures ( $T_{\mathrm{g}}$ 's) for those polymers synthesized in the present study were determined to be $-121.4{ }^{\circ} \mathrm{C}$ for PDMSMA-13, $-120.8^{\circ} \mathrm{C}$ for PDMSMA-27 and $-121.1{ }^{\circ} \mathrm{C}$ for PDMSMA-168, respectively. In the case of poly(2-ethylhexyl acrylate) (P2EHA) [34], the glass transition temperature was dependent on its molecular weight and was lowered with the decrease in the number average molecular weight. Contrary to this, such molecular weight dependence of $T_{\mathrm{g}}$ was hardly observed in the present study. DSC results revealed that three types of PDMSMA obtained in the present study showed rubbery state at the operating temperature of membrane transport studies $\left(40^{\circ} \mathrm{C}, 50^{\circ} \mathrm{C}\right.$ and $\left.60^{\circ} \mathrm{C}\right)$.

\subsection{Transport of $\mathrm{KCl}$ through the PDMSMA Polymeric Pseudo-Liquid Membranes}

$\mathrm{KCl}$ transport adopting dibenzo-18-crown-6 (DB18C6) as a potassium ion carrier [49] was studied so that the results obtained in the present study could be compared with results previously reported [33-37].

Figure 3 shows time-transport curves of $\mathrm{KCl}$ through the polymeric pseudo-liquid membrane (PPLM) composed of PDMSMA-168 and DB18C6 and the corresponding control membrane at the experimental temperature of $40{ }^{\circ} \mathrm{C}, 50{ }^{\circ} \mathrm{C}$ and $60{ }^{\circ} \mathrm{C}$, respectively. The steady state flux for each membrane was determined from the straight line of each time-transport curves. Against anticipation, $\mathrm{KCl}$ was transported (a) at $40^{\circ} \mathrm{C}$

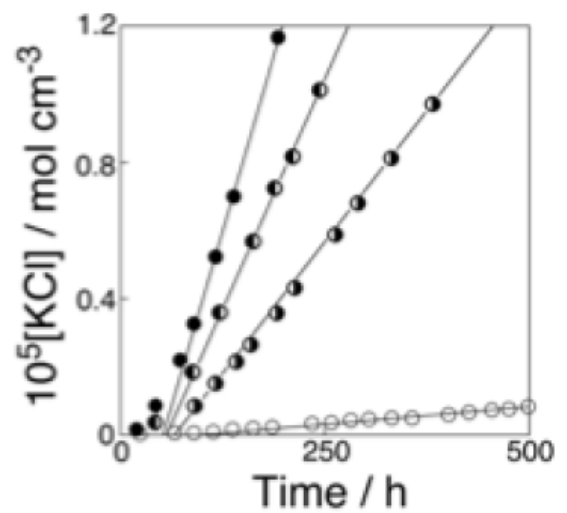

(b) at $50^{\circ} \mathrm{C}$

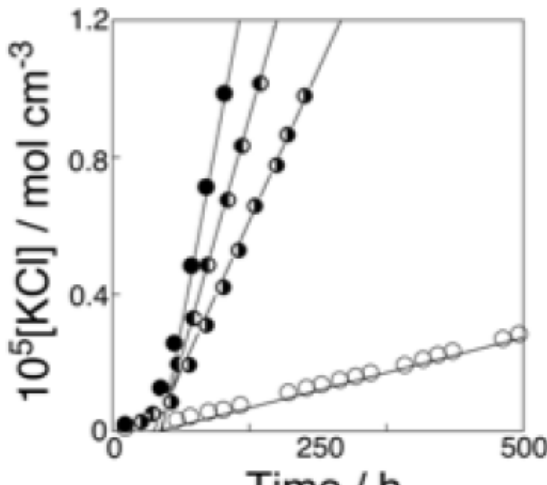

Time / h (c) at $60^{\circ} \mathrm{C}$

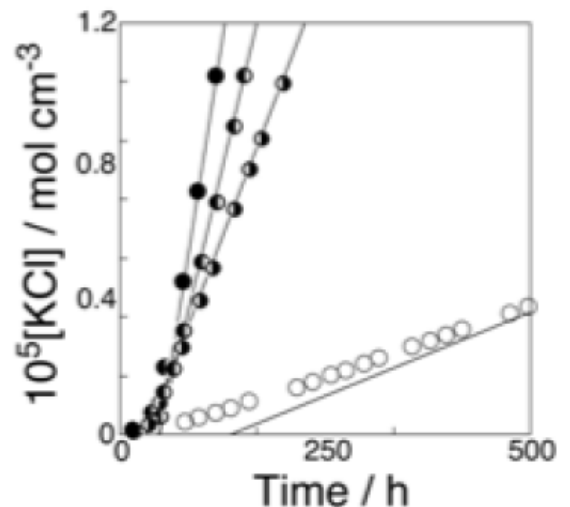

Figure 3: Time-transport curves of $\mathrm{KCl}$ through the PDMSMA-168/DB18C6 polymeric pseudo-liquid membranes. (Operating temp., $40{ }^{\circ} \mathrm{C}(313 \mathrm{~K})(\mathrm{a}), 50^{\circ} \mathrm{C}(323 \mathrm{~K})(\mathrm{b})$ and $\left.60{ }^{\circ} \mathrm{C}(333 \mathrm{~K})(\mathrm{c}) ;[\mathrm{KCl}]_{0}=1.0 \times 10^{-4} \mathrm{~mol} \mathrm{~cm}^{-3}\right)$. (DB18C6 content, O, control; ()$^{2}$, 2.44 wt. \%; (, 4.76 wt.\%;, 6.98 wt. \%). 
through the control membrane. In other words, $\mathrm{KCl}$ was transported through the PDMSMA liquid membrane by simple diffusion, which composed of the diffusion of free ion and uncomplexed ion pairs. In addition to the above results, the slope for the time-transport curves of $\mathrm{K}^{+}$transport was increased with the rise in the operating temperature.

When the membrane transport of uni-univalent salt, such as $\mathrm{KCl}$ and so on, is transported through a given liquid membrane simultaneously by simple diffusion and facilitated transport, the flux of uni-univalent salt can be represented by eq. (2) $[50,51]$.

$J_{\mathrm{C}, \mathrm{obs}}=\left(D_{\mathrm{CA}} k / \delta\right)\left[\mathrm{K}^{+}\right]^{2}+\left(D_{\mathrm{CLA}} k K[\mathrm{DB} 18 \mathrm{C} 6] / \delta\right)\left[\mathrm{K}^{+}\right]^{2}$

In Figure 4, the product $J_{\mathrm{C}, \text { obs }}$ and membrane thickness $\delta, J_{C}\left(\mathrm{~mol} \mathrm{~cm} \mathrm{~cm}{ }^{-2} \mathrm{~h}^{-1}\right)$, which is a flux per unit membrane thickness, per unit membrane area and per unit time is plotted as a function of carrier concentration. The relationships for the operating temperature of $40{ }^{\circ} \mathrm{C}, 50{ }^{\circ} \mathrm{C}$ and $60{ }^{\circ} \mathrm{C}$ are shown together in Figure 4. The flux $J_{C}$ gives a straight line, passing though that for each control experiment. The relationship shown in Figure $\mathbf{4}$ can be explained by eq. (2). The relationship shown in Figure 4 revealed that the membrane transport was carried out by carrierdiffusion mechanism $[50,51]$ not by fixed-site jumping one $[17,52,53]$. In other words, the present membrane matrix of PDMSMA was fluid enough so that carrier and carrier/substrate complex were able to freely diffuse within the membrane. As a result, membrane transport of $\mathrm{K}^{+}$was carried out like usual supported liquid membranes $[50,51]$.

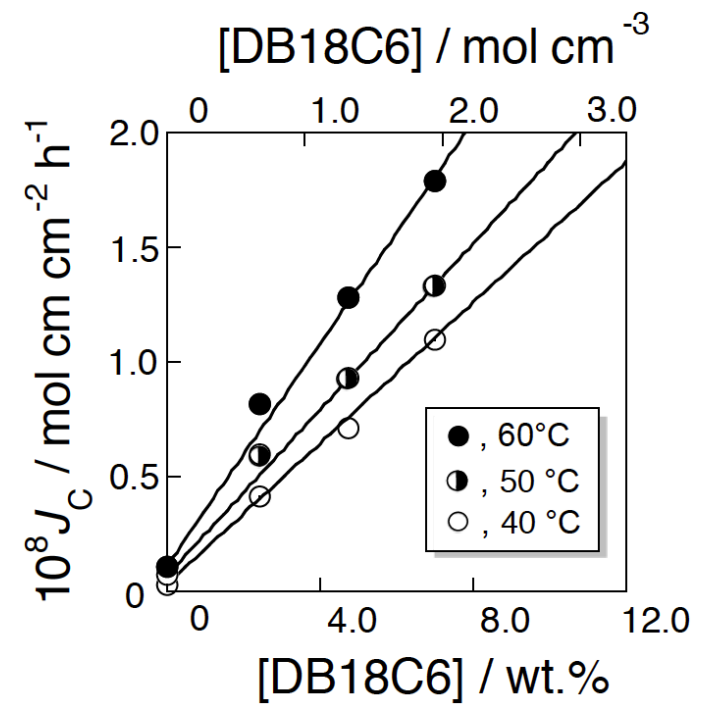

Figure 4: Relationship between $\mathrm{KCl}$ flux and the DB18C6 concentration through PDMSMA-168/DB18C6 polymeric pseudo-liquid membranes. $\left([\mathrm{KCl}]_{0}=1.0 \times 10^{-4} \mathrm{~mol} \mathrm{~cm}^{-3}\right)$.
Following the $\mathrm{K}^{+}$flux, which is represented by eq. (2), $\mathrm{K}^{+}$flux should be proportional to the square of the initial feed concentration of $\mathrm{K}^{+}$. To this end, the relationship between $\mathrm{K}^{+}$flux and the initial feed $\mathrm{K}^{+}$ concentration through PDMSMA-168/DB18C6 liquid membrane at $50{ }^{\circ} \mathrm{C}$ was studied. In Figure 5 , the $\mathrm{K}^{+}$ flux facilitated by carrier and that of simple diffusion are plotted as a function of initial $\mathrm{K}^{+}$feed concentration. As expected, the plots of logarithm of both $\mathrm{K}^{+}$fluxes against the logarithm of the initial $\mathrm{KCl}$ concentration gave a slope of two.

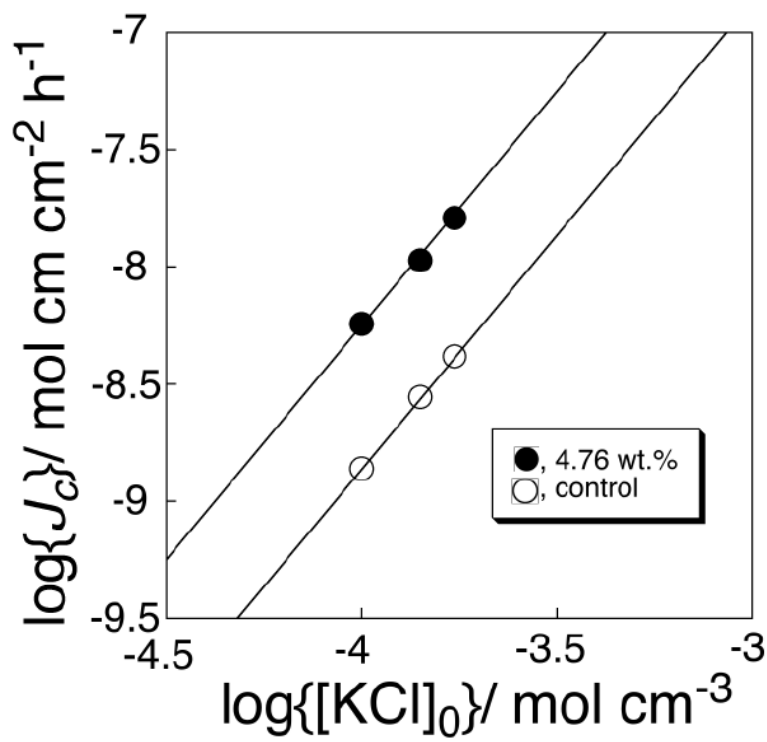

Figure 5: Dependence of facilitated $\mathrm{KCl}$ and simple diffusion fluxes on $\mathrm{KCl}$ initial feed concentration at $50{ }^{\circ} \mathrm{C}(323 \mathrm{~K})$. (PDMSMA-168/DB18C6 polymeric pseudo-liquid membrane; $[\mathrm{DB} 18 \mathrm{C} 6]=1.32 \times 10^{-4} \mathrm{~mol} \mathrm{~cm}^{-3}$ )

In the present study, three types of membrane matrix with different molecular weight were synthesized. Transport of $\mathrm{KCl}$ through PDMSMA13/DB18C6 and PDMSMA-27/DB18C6 PPLMs at three different operating temperatures, such as $40{ }^{\circ} \mathrm{C}, 50{ }^{\circ} \mathrm{C}$ and $60{ }^{\circ} \mathrm{C}$, were also studied. The activation energy of membrane transport can be determined from fluxes thus obtained. As shown in Figure 6, Arrhenius plot of $\mathrm{K}^{+}$flux vs. reciprocal of absolute temperature yields activation energy of $\mathrm{K}^{+}$transport. Figure 6 revealed that the flux of $\mathrm{K}^{+}$was increased with the decrease in the molecular weight of membrane matrix PDMSMA and increased with the rise in the operating temperature. From the slope of the straight line, the activation energy of $\mathrm{K}^{+}$transport for each membrane was determined. The determined activation energies are summarized in Table 2 . In the table, number average molecular weights and glass transition temperatures for those membrane matrices are also given for convenience. 
(a)

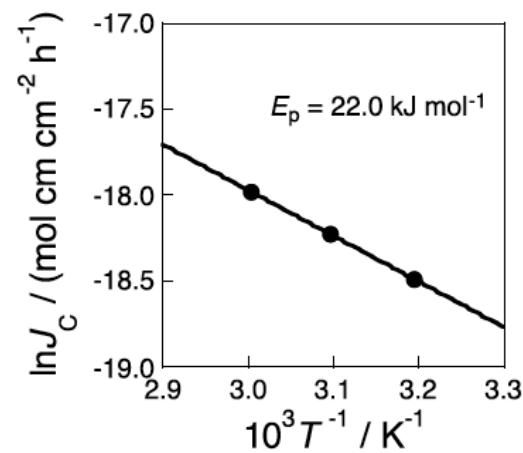

(b)

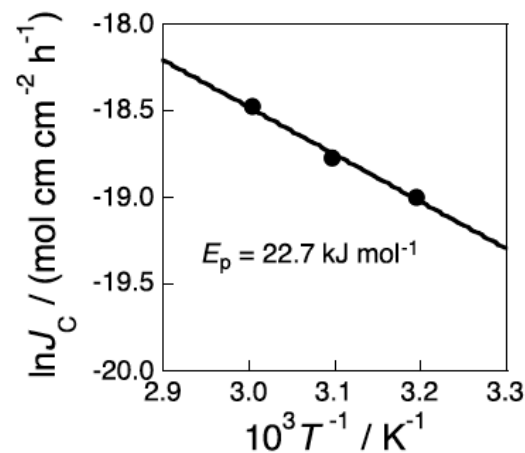

(c)

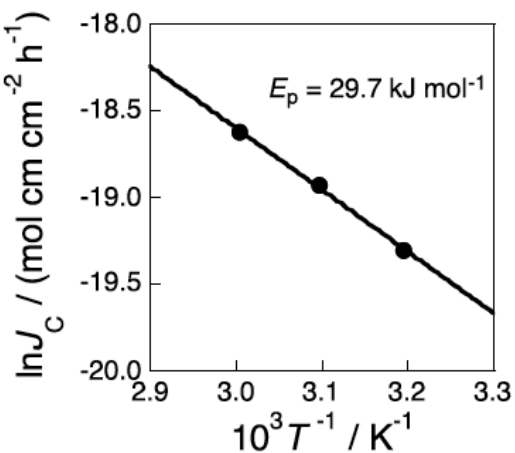

Figure 6: Temperature dependence of $\mathrm{KCl}$ transport through the PDMSMA/DB18C6 polymeric pseudo-liquid membranes. (PDMSMA-13/DB18C6 membrane (a), PDMSMA-27/DB18C6 membrane (b) and PDMSMA-168/DB18C6 membrane (c); $\left.[D B 18 C 6]=6.77 \times 10^{-5} \mathrm{~mol} \mathrm{~cm}^{-3}(2.44 \mathrm{wt} . \%) ;[\mathrm{KCl}]_{0}=1.0 \times 10^{-4} \mathrm{~mol} \mathrm{~cm}^{-3}\right)$.

Table 2: Activation Energy for $\mathrm{KCl}$ Transport

\begin{tabular}{|c|c|c|c|}
\hline \multirow{2}{*}{ PPLM } & \multirow{2}{*}{$\boldsymbol{M}_{\mathbf{n}}$} & $\boldsymbol{E}_{\mathbf{P}}$ & $\boldsymbol{T}_{\mathbf{g}}$ \\
\cline { 3 - 4 } & & $\mathbf{k J ~ m o l}^{-1}$ & ${ }^{\circ} \mathbf{C}$ \\
\hline \hline PDMSMA-13 & $1.27 \times 10^{4}$ & 22.0 & -121.4 \\
\hline PDMSMA-27 & $2.65 \times 10^{4}$ & 22.7 & -120.8 \\
\hline PDMSMA-168 & $1.68 \times 10^{5}$ & 29.7 & -121.1 \\
\hline
\end{tabular}

Three types of membrane matrix PDMSMA studied in the present study showed rubbery state under the membrane transport conditions. The fluidity of membrane matrix was expected to increase with the decrease in molecular weight of PDMSMA. This will lead to enhancement in $\mathrm{K}^{+}$flux and to decrease in activation energy of diffusion within the membrane. As anticipated, the activation energy of membrane transport was decreased with the decrease in molecular weight.

Figure 7 summarizes relationship between the activation energy of $\mathrm{K}^{+}$transport and the corresponding glass transition temperature. The numeral in the parenthesis shows the number average molecular weight. Unfortunately, molecular weights of membrane matrix are scattered and it is difficult to discuss the relationship all together. As mentioned above, among the polymeric pseud-liquid membranes from PDMSMA, the activation energy of $\mathrm{K}^{+}$transport was decreased with the decrease in molecular weight. Comparing the activation energy for PDMSMA-168 and PC18MA (D), of which molecular weights were similar; PDMSMA-168 with lower glass transition temperature gave lower activation energy. Similar tendency can be found among PDMSMA-13, PDMSMA-27 and PC12MA (•), and between P2EHA and P2EHMA $(\mathcal{O})$. From Figure
7, a membrane matrix with lower glass transition temperature and lower molecular weight will give lower activation energy of $\mathrm{K}^{+}$transport, which is not to mention.

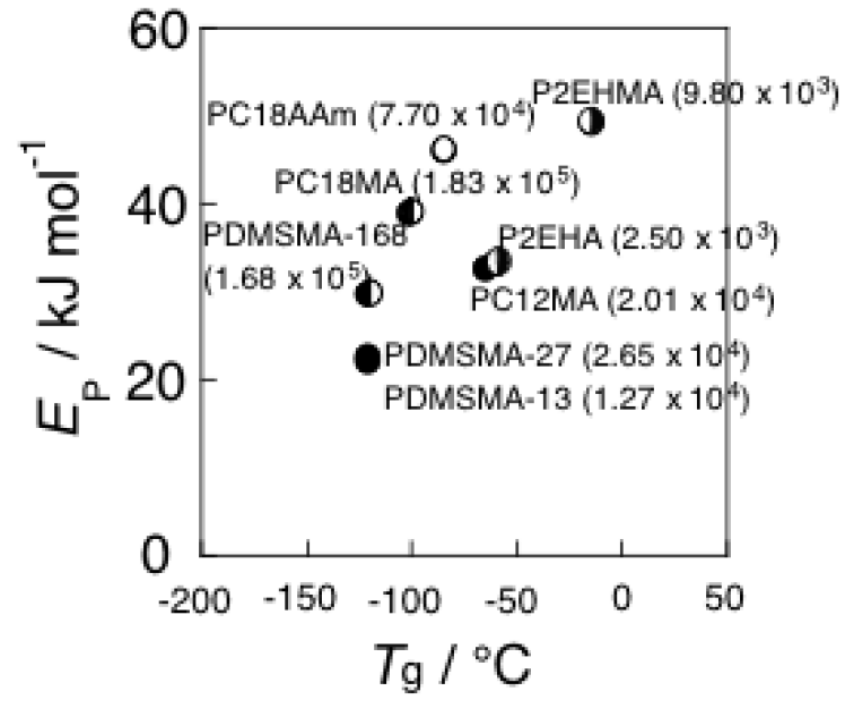

Figure 7: Relationship between activation energy of $\mathrm{KCl}$ transport and glass transition temperature of membrane matrix.

In Table 3, the fluxes studied in the present study are summarized together with previous results for polymeric pseudo-liquid membranes from P2EHMA [33], P2EHA [34], PC12MA [35], PC18MA [36], PC18AAm [37], supported liquid membrane [54] and polymer inclusion membrane [16] so that the present studies can be compared with those results. In the case of polymer inclusion membrane [16], dicyclohexyl18-crown-6 (DC18C6) was used as a carrier instead of DB18C6. The membrane performances for those membranes are given as normalized fluxes, which are fluxes per unit membrane area, per unit membrane 
Table 3: Comparison of Normalized $\mathrm{K}^{+}$Flux Values for Various Membranes

\begin{tabular}{|c|c|c|c|}
\hline \multirow{3}{*}{ Liquid membrane } & $J\left(\right.$ normalized flux of $\left.\mathrm{K}^{+}\right)$ & \multirow{3}{*}{ Flux ratio ${ }^{a}$} & \multirow{2}{*}{ Operating temperature } \\
\hline & $\left(\mathrm{mol} \cdot \mathrm{cm} \cdot \mathrm{cm}^{-2} \cdot \mathrm{h}^{-1}\right)$ & & \\
\hline & $\left(\mathrm{mol} \cdot \mathrm{cm}^{-3}\right)\left(\mathrm{mol} \cdot \mathrm{cm}^{-3}\right)^{2}$ & & ${ }^{\circ} \mathrm{C}$ \\
\hline PDMSMA-13/DB18C6 ${ }^{\mathrm{b}}$ & $1.38 \times 10^{4}$ & 82 & 40 \\
\hline PDMSMA-13/DB18C6 ${ }^{b}$ & $1.79 \times 10^{4}$ & 107 & 50 \\
\hline PDMSMA-13/DB18C6 ${ }^{\mathrm{b}}$ & $2.29 \times 10^{4}$ & 137 & 60 \\
\hline PDMSMA-27/DB18C6 ${ }^{c}$ & $8.26 \times 10^{3}$ & 49 & 40 \\
\hline PDMSMA-27/DB18C6 ${ }^{c}$ & $1.04 \times 10^{4}$ & 62 & 50 \\
\hline PDMSMA-27/DB18C $6^{\mathrm{C}}$ & $1.40 \times 10^{4}$ & 84 & 60 \\
\hline PDMSMA-168/DB18C6 ${ }^{d}$ & $6.10 \times 10^{3}$ & 37 & 40 \\
\hline PDMSMA-168/DB18C6 ${ }^{d}$ & $8.88 \times 10^{3}$ & 53 & 50 \\
\hline PDMSMA-168/DB18C6 ${ }^{d}$ & $1.21 \times 10^{4}$ & 72 & 60 \\
\hline PC18AAm/DB18C6 & $6.75 \times 10^{3}$ & 40 & 70 \\
\hline PC18MA/DB18C6 & $6.89 \times 10^{3}$ & 41 & 60 \\
\hline PC12MA/DB18C6 & $5.79 \times 10^{4}$ & 347 & 40 \\
\hline P2EHA/DB18C6 & $5.88 \times 10^{3}$ & 35 & 40 \\
\hline P2EHMA/DB18C6 & $6.20 \times 10^{3}$ & 37 & 40 \\
\hline $\mathrm{CHCl}_{3} / \mathrm{DB} 18 \mathrm{C} 6^{\mathrm{e}}$ & $1.67 \times 10^{2}$ & 1 & 25 \\
\hline PIM/DC18C6 ${ }^{f}$ & $2.37 \times 10^{2}$ & 1.4 & 25 \\
\hline
\end{tabular}

${ }^{\mathrm{a}}$ Flux ratios are the relative values; the flux value for the supported liquid membrane being set as unity

${ }^{\mathrm{b}} M_{\mathrm{n}}=1.27 \times 10^{4}$.

${ }^{\mathrm{C}} M_{\mathrm{n}}=2.65 \times 10^{4}$.

${ }^{\mathrm{d}} M_{\mathrm{n}}=1.68 \times 10^{5}$.

${ }^{\mathrm{e}}$ cited from ref. [54]

'cited from ref. [16].

thickness, per unit carrier concentration and per square of unit substrate concentration.

As expected, polymeric pseudo liquid membranes consisting of PDMSMA showed higher normalized $\mathrm{K}^{+}$ fluxes than a usual liquid membrane and a polymer inclusion membrane. However, against the anticipation from glass transition temperature of membrane matrix, the newly obtained membrane matrix, PDMSMA, did not give higher normalized $\mathrm{K}^{+}$fluxes comparing with previous results. So far the polymeric pseudo-liquid membrane consisting of poly(dodecyl methacrylate), PC12MA, and DB18C6 gave the highest membrane performance. The membrane performance of polymeric pseudo-liquid membrane might be governed by various factors, such as glass transition temperature of membrane matrix, molecular weight, partition coefficient of the solute between water and the membrane matrix, equilibrium constant for the association between substrate and carrier, concentration of carrier, diffusion coefficient of the complexed solute and so on. Due to factors enumerated above, the present membrane did not show better membrane performance.
3.3. Transport of $\mathrm{CsCl}$ through the PDMSMA Polymeric Pseudo-Liquid Membranes

The performance of polymeric pseudo-liquid membrane is exclusively dependent on the nature of carrier like usual liquid membranes. From this, dibenzo21-crow-7 (DB21C7) $[55,56]$ was adopted as a carrier instead of DB18C6, and membrane transport of $\mathrm{Cs}^{+}$ was studied. Since isotope ${ }^{135} \mathrm{Cs}$, which is formed in nuclear reactors, has a long half-life of $2.3 \times 10^{6}$ years, ${ }^{137}$ Cs 30.17 years, ${ }^{134}$ Cs 2 years and so on $[57,58]$. Figure 8 shows time-transport curves of $\mathrm{CsCl}$ through PDMSMA-168/DB21C7 membranes and the corresponding control membrane at $60{ }^{\circ} \mathrm{C}$. The flux dependence on carrier concentration is shown in Figure 9. Figure 9 revealed that $\mathrm{CsCl}$ was also transported through the membrane by a mobile carrier mechanism as $\mathrm{KCl}$ was transported through the PDMSMA/DB18C6 polymeric pseudo-liquid membrane.

\subsection{Chiral Separation of Racemic Mixture of Phenyglycine (Phegly)}

The results obtained in the previous section suggested that polymeric pseudo-liquid membrane 


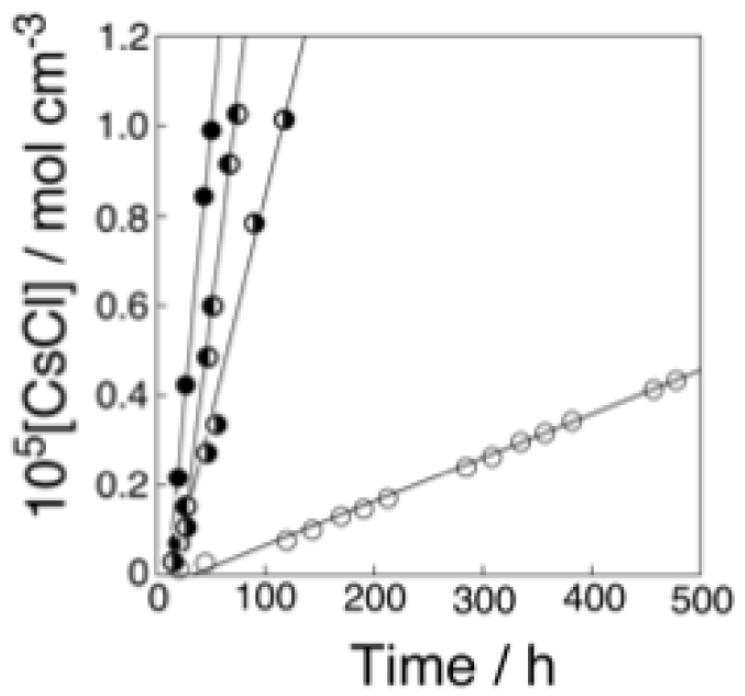

Figure 8: Time-transport curves of $\mathrm{CsCl}$ through the PDMSMA-168/DB21C7 polymeric pseudo-liquid membranes. (Operating temp., $60{ }^{\circ} \mathrm{C}(333 \mathrm{~K})(\mathrm{c}) ;[\mathrm{CsCl}]_{0}=1.0 \times 10^{-4} \mathrm{~mol}$ $\mathrm{cm}^{-3}$ ). (DB21C7 content, O, control; (O, 2.44 wt.\%; D, 4.76 wt. \%; , 6.98 wt.\%).

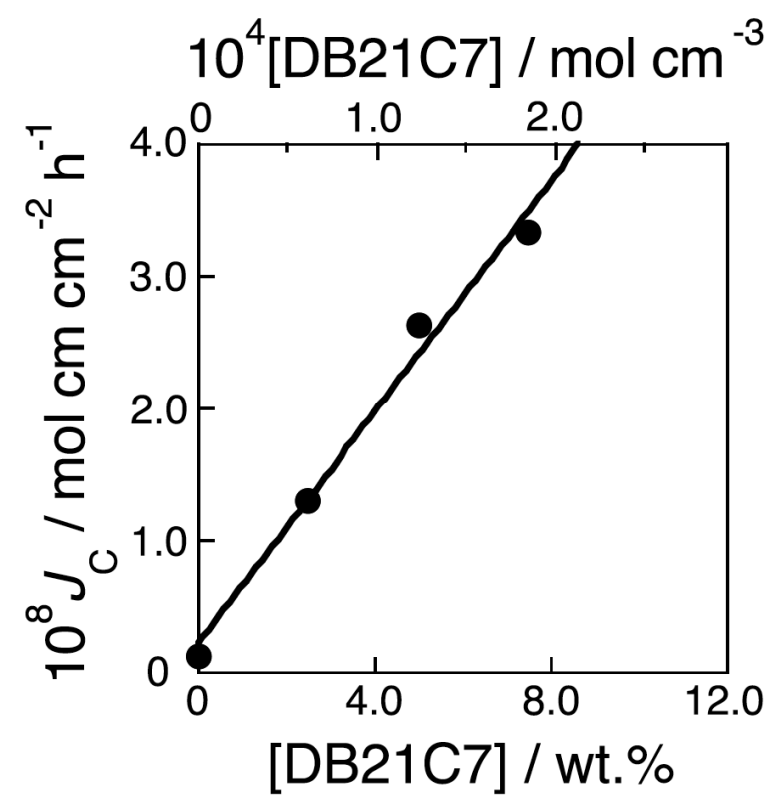

Figure 9: Relationship between $\mathrm{CsCl}$ flux and the $\mathrm{DB} 21 \mathrm{C} 7$ concentration through PDMSMA-168/DB21C7 polymeric pseudo-liquid membranes. $\left([\mathrm{KCl}]_{0}=1.0 \times 10^{-4} \mathrm{~mol} \mathrm{~cm}^{-3}\right)$.

consisting of PDMSMA and carrier with chiral environment was expected to show enantioselective transport ability. So far polymeric pseudo-liquid membranes from PC12MA [35], PC18MA [36] and PC18AAm [37] showed not only transport ability of alkali metal ions but also chiral separation ability adopting O-allyl- $\mathrm{N}$-(9-anthracenylmethyl)cinchonidinium bromide (AAMC) as a chiral carrier. Cinchona alkaloids have been used as resolving agents for chiral binaphthols [59], chiral acids [60], amino acid derivatives [60, 61] and oligopeptides [62]. Cinchona alkaloid was also used as a carrier for chiral separation with membranes [63]. From those studies, AAMC was adopted as a carrier for optical resolution. A racemic mixture of phenylglycine (Phegly) was adopted as a model racemate.

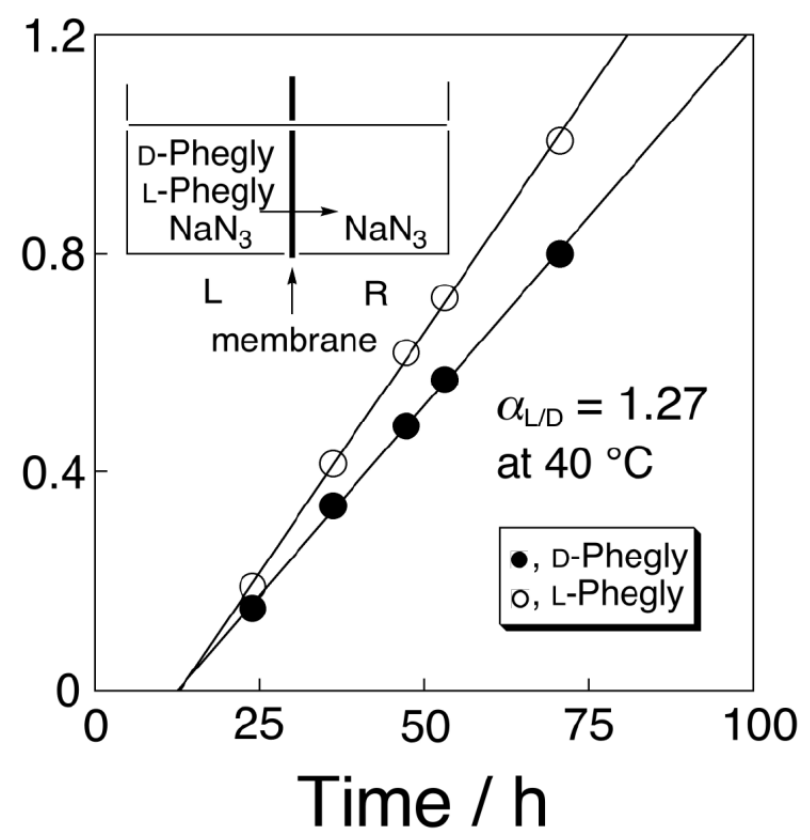

Figure 10: Chiral separation of racemic mixture of Phegly through the PDMSMA-168/AAMC polymeric pseudo-liquid membrane. (Operating temp., $40{ }^{\circ} \mathrm{C}(313 \mathrm{~K})$; [AAMC] $=4.03$ x $10^{-5} \mathrm{~mol} \mathrm{~cm}^{-3} ;$ [D-phegly $]_{0}=[\text { L-Phegly }]_{0}=1.00 \times 10^{-6} \mathrm{~mol}$ $\mathrm{cm}^{-3}$ ).

Time-transport curves of racemic mixture of Phegly through PDMSMA-168/AAMC polymeric pseudo-liquid membrane at $40{ }^{\circ} \mathrm{C}$ is shown in Figure 10. L-Phegly was transported through the membrane in preference to the antipode as reported [35-37, 63]. At the operating temperature of $40{ }^{\circ} \mathrm{C}$, the permselectivity toward the L-isomer was determined to be 1.27 .

\section{CONCLUSIONS}

Novel liquid membrane system, which is named polymeric pseudo-liquid membrane, was constructed from polymethacrylate derivative bearing oligodimethylsiloxane (PDMS), of which glass transition temperature was determined to be around $-121^{\circ} \mathrm{C}$, as a membrane matrix. In the present study, dibenzo-18crown-6 (DB18C6), dibenzo-21-crown-7 (DB21C7) or $\mathrm{O}$-allyl- $\mathrm{N}$-(9-anthracenylmethyl)cinchonidinium bromide (AMCC) was adopted as a carrier for $\mathrm{KCl}$ transport, $\mathrm{CsCl}$ transport or optical resolution of racemic mixture of phenylglycine (Phegly), respectively. The results of $\mathrm{KCl}$ and $\mathrm{CsCl}$ transports revealed that the membrane 
transport was attained by carrier-diffusion mechanism like usual liquid membranes. L-Phegly was selectively transported from racemic mixture of Phegly and the permselectivity toward the L-enantiomer of 1.27 was observed. The present study led the conclusion that PDMSMA can be applicable not only to membrane transport of alkali metal ions, such as $\mathrm{K}^{+}$and $\mathrm{Cs}^{+}$, but also to chiral separation.

\section{NOMENCLATURE}
$D_{\mathrm{CA}} \quad=$ diffusion coefficient of the free solute $\left[\mathrm{cm}^{2} \mathrm{~h}^{-1}\right]$
$D_{\text {CLA }}=$ diffusion coefficient of the complexed solute $\left[\mathrm{cm}^{2} \mathrm{~h}^{-1}\right]$
$J_{\mathrm{C}} \quad=$ total flux of the diffusing solute, $\mathrm{K}^{+}$, across the membrane per unit membrane thickness $\left(J_{C}=\delta \times J_{C, \text { obsd }}\right)\left[\mathrm{mol} \mathrm{cm} \mathrm{cm}{ }^{-2}\right.$ $\left.\mathrm{h}^{-1}\right]$

$J_{\mathrm{C}, \text { obsd }}=$ observed total flux of the diffusing solute, $\mathrm{K}^{+}$, across the membrane $\left[\mathrm{mol} \mathrm{cm} \mathrm{cm}^{-2} \mathrm{~h}^{-1}\right.$ ]

$k=$ partition coefficient of the solute between water and the organic membrane $\left[\mathrm{mol}^{-1}\right.$ $\mathrm{cm}^{3}$ ]

$K=$ equilibrium constant for the association $\left[\mathrm{mol}^{-1} \mathrm{~cm}^{3}\right.$ ]

$\delta \quad=$ membrane thickness $[\mathrm{cm}]$

$[\mathrm{DB} 18 \mathrm{C} 6]=$ total concentration of complexed and uncompolexed carrier, DB18C6 in the membrane $\left[\mathrm{mol} \mathrm{cm}^{-3}\right]$

$\left[\mathrm{K}^{+}\right]=$concentration of the diffusing solutes. $\mathrm{K}^{+}$, in the source phase $\left[\mathrm{mol} \mathrm{cm}^{-3}\right]$

\section{REFERENCES}

[1] Ho WSW, Sirkar KK. Membrane handbook; New York: Chapman \& Hall; 1992. https://doi.org/10.1007/978-1-4615-3548-5

[2] Matsuura T. Synthetic membranes and membrane separation processes. Boca Raton: CRC Press; 1994.

[3] Mulder M. Basic principles of membrane technology. 2nd ed. Dordrecht: Kluwer Academic Publishers; 1996.

[4] Baker RW Membrane technology and applications. 3rd ed. West Sussex: Wiley; 2012.

[5] Strathmann $H$. Introduction to membrane science and technology. Weinheim: Wiley-VCH; 2013.

[6] Danesi PR, Reichley-Yinger L, Rickert PG. Lifetime of supported liquid membranes: The influence of interfacial properties, chemical composition and water transport on the long-term stability of the membranes. J Membr Sci 1987; 31: 117-45. https://doi.org/10.1016/S0376-7388(00)82223-1
[7] Takeuchi H, Takahashi K, Goto W. Some observations on the stability of supported liquid membranes. J Membr Sci 1987; 34: 19-31. https://doi.org/10.1016/S0376-7388(00)80018-6

[8] Zha FF, Fane AG, Fell CJD. Schofield RW. Critical displacement of a supported liquid membrane. J Membr Sci 1992; 75: 69-80.

https://doi.org/10.1016/0376-7388(92)80007-7

[9] Zha FF, Fane AG, Fell CD. Instability mechanisms of supported liquid membranes in phenol transport process. J Membr Sci 1995, 107, 59-74. https://doi.org/10.1016/0376-7388(95)00104-K

[10] Zha FF, Fane AG, Fell CJD. Effect of surface tension gradients on stability of supported liquid membranes. J Membr Sci 1995; 107: 75-86. https://doi.org/10.1016/0376-7388(95)00103-J

[11] Yang XJ, Fane AG. Performance and stability of supported liquid membranes using LIX 984N for copper transport. J Membr Sci 1999; 156: 251-63.

https://doi.org/10.1016/S0376-7388(98)00351-2

[12] Shinkai S, Nakamura S, Tachiki S, Manabe O, Kajiyama T. Thermocontrol of ion permeation through ternary composite membranes composed of polymer/liquid crystal/amphiphilic crown ethers. J Am Chem Soc 1985; 107: 3363-5. https://doi.org/10.1021/ja00297a061

[13] Shinkai S, Torigoe K, Manabe O, Kajiyama T. 'Complete' thermocontrol of ion permeation through ternary composite membranes composed of polymer-liquid crystal-fluorocarboncontaining crown ethers. J Chem Soc Chem Commun 1986; 12: $933-5$.

https://doi.org/10.1039/C39860000933

[14] Sugiura M. Coupled-ion transport through a solvent polymeric membrane. J Colloid Interface Sci 1981; 81: 385-9. https://doi.org/10.1016/0021-9797(81)90419-7

[15] Sugiura M, Kikkawa M, Urita S. Effect of plasticizer on carrier-mediated transport of zinc ion through cellulose triacetate membranes. Sep Sci Technol 1987; 22: 2263-8. https://doi.org/10.1080/01496398708068612

[16] Schow AJ, Peterson RT, Lamb JD. Polymer inclusion membranes containing macrocyclic carriers for use in cation separations. J Membr Sci 1996; 111: 291-5. https://doi.org/10.1016/0376-7388(95)00295-2

[17] Riggs JA, Smith BD. Facilitated transport of small carbohydrates through plasticized cellulose triacetate membranes. Evidence for fixed-site jumping transport mechanism. J Am Chem Soc 1997; 119: 2765-6. https://doi.org/10.1021/ja964103m

[18] Kusumocahyo SP, Kanamori T, Sumaru K, Aomatsu S Matsuyama H, Teramoto $M$, Shinbo T. Development of polymer inclusion membranes based on cellulose triacetate: carrier-mediated transport of cerium (III). J Membr Sci 2004; 244: 251-7.

https://doi.org/10.1016/j.memsci.2004.07.013

[19] Nghiem LD, Mornane P, Potter ID, Perera JM, Cattrall RW, Kolev SD. Extraction and transport of metal ions and small organic compounds using polymer inclusion membranes (PIMs). J Membr Sci 2006; 281: 7-41. https://doi.org/10.1016/j.memsci.2006.03.035

[20] Sgarlata C, Arena G, Longo E, Zhang D, Yang Y, Bartsch RA. Heavy metal separation with polymer inclusion membranes. J Membr Sci 2008; 323: 444-51. https://doi.org/10.1016/j.memsci.2008.07.004

[21] Inês M, Almeida GS, Cattrall RW, Kolev SD. Recent trends in extraction and transport of metal ions using polymer inclusion membranes (PIMs). J Membr Sci 2012; 415-416: 9-23. https://doi.org/10.1016/j.memsci.2012.06.006

[22] Inês M, Almeida GS, Silva AML, Cattrall RW, Kolev SD. A study of the ammonium ion extraction properties of polymer inclusion membranes containing commercial 
dinonylnaphthalene sulfonic acid. J Membr Sci 2015; 478: 155-62.

https://doi.org/10.1016/j.memsci.2015.01.005

[23] Neplenbroek AM, Bargeman D, Smolders CA. Supported liquid membranes: stabilization by gelation. J Membr Sci 1992; 67: 149-65.

https://doi.org/10.1016/0376-7388(92)80022-C

[24] Miyako E, Maruyama T, Kamiya N, Goto M. Selective separation of organic acids through a lipase-facilitated organogel membrane. Membrane 2004; 29: 236-43. https://doi.org/10.5360/membrane.29.236

[25] Kemperman AJB, Rolevink HHM, Bargeman D, van den Boomgaard Th, Strathmann H. Stabilization of supported liquid membranes by interfacial polymerization top layers. J Membr Sci 1998; 138: 43-55. https://doi.org/10.1016/S0376-7388(97)00202-0

[26] Wang Y, Thio YS, Doyle FM. Formation of semi-permeable polyamide skin layers on the surface of supported liquid membranes. J Membr Sci 1998; 147: 109-16.

https://doi.org/10.1016/S0376-7388(98)00129-X

[27] Fortunato R, Afonso CAM, Reis MAM, Crespo JG. Supported liquid membranes using ionic liquids: study of stability and transport mechanisms. J Membr Sci 2004; 242: 197-209. https://doi.org/10.1016/j.memsci.2003.07.028

[28] de los Ríos AP, Hernández-Fernández FJ, Tomás-Alonso $F$, Palacios JM, Gómez D, Rubio M, Víllora G. A SEM-EDX study of highly stable supported liquid membranes based on ionic liquids. J Membr Sci 2007; 300: 88-94.

https://doi.org/10.1016/j.memsci.2007.05.010

[29] de los Ríos AP, Hernández-Fernández FJ, Tomás-Alonso F, Rubio M, Gómez D, Villora G. On the importance of the nature of the ionic liquids in the selective simultaneous separation of the substrates and products of a transesterification reaction through supported ionic liquid membranes. J Membr Sci 2008; 307: 233-38.

https://doi.org/10.1016/j.memsci.2007.09.020

[30] Pirkle WH, Doherty EM. Enantioselective transport through a silicone-supported liquid membrane. J Am Chem Soc 1989; 111: 4113-4. https://doi.org/10.1021/ja00193a060

[31] Meier W, Nardin C, Winterhalter M. Reconstruction of channel proteins in (polymerized) ABA triblock copolymer membranes. Angew Chem Int Ed 2000; 39: 4599-602.

https://doi.org/10.1002/1521 3773(20001215)39:24<4599::AID-ANIE4599>3.0.CO;2-Y

[32] Sakiyama T, Aoki T, Yoshikawa M. ABA triblock copolymer POE-block-PDMS-block-POE as a component for liquid membranes. Membrane 2004; 29: 377-83. https://doi.org/10.5360/membrane.29.377

[33] Naito D, Yoshikawa M, Maeda S, Okushita H, Polymeric pseudo-liquid membranes from poly(2-ethylhexyl methacrylate). Polym J 2009; 41: 1005-10.

https://doi.org/10.1295/polymj.PJ2009113

[34] Murai Y, Asaoka S, Yoshikawa M. Polymeric pseudo-liquid membrane as a stable liquid membrane-Evidence for carrierdiffusion mechanism. J Membr Sci 2011; 380: 216-22.

https://doi.org/10.1016/j.memsci.2011.07.009

[35] Murai Y, Yoshikawa M. Polymeric pseudo-liquid membranes from poly(dodecyl methacrylate): $\mathrm{KCl}$ transport and optical resolution. Polym J 2013; 45: 1058-63. https://doi.org/10.1038/pj.2013.30

[36] Tsujimoto H, Yoshikawa M. Polymeric pseudo-liquid membranes from poly(octadecyl methacrylate). J Membr Sci 2013; 445: 8-14.

https://doi.org/10.1016/j.memsci.2013.05.039

[37] Shiono H, Yoshikawa M. Polymeric pseudo-liquid membranes from poly(N-oleylacrylamide). Membranes 2014; 4: 210-226. https://doi.org/10.3390/membranes4020210

[38] Ho SV, Sheridan PW, Krupetsky E. Supported polymeric liquid membranes for removing organics from aqueous solutions I. Transport characteristics of polyglycol liquid membranes. J Membr Sci 1996; 112: 13-27.

https://doi.org/10.1016/0376-7388(95)00047-X

[39] Harriott P, Ho SV. Mass transfer analysis of extraction with a supported polymeric liquid membrane. J Membr Sci 1997 135: 55-63.

https://doi.org/10.1016/S0376-7388(97)00116-6

[40] Ho SV. A supported polymeric liquid membrane process for removal of carboxylic acids from a waste stream. Environ Prog 1999; 18: 273-9. https://doi.org/10.1002/ep.670180414

[41] Dastgir MG, Peeva LG, Livingston AG. The performance of composite supported polymeric liquid membranes in the membrane aromatic recovery system (MARS). Chem Eng Sci 2005; 60: 7034-44 https://doi.org/10.1016/j.ces.2005.06.015

[42] The glass transition temperature of PC18MA, which was reported to be $-100{ }^{\circ} \mathrm{C}[43,44]$, could not be observed in the previous study [36]. The $T_{\mathrm{g}}$ value of PC18MA was reinvestigated in the present study and determined to be $101.2^{\circ} \mathrm{C}$.

[43] Mercier JP. Quelques aspects de la physice des hauts polymeres. Ind Chim Belge 1965; 30: 813-9.

[44] Bowden MJ, O'Donnell JH. Radiation-induced solid-state polymerization of derivatives of methacrylic acid. III. An electron spin resonance study of radical reactions in irradiated octadecyl methacrylate. J Polym Sci: Part A 1969; 7: 1665-74. https://doi.org/10.1002/pol.1969.150070710

[45] Kice JL. Inhibition of polymerization. I. Methyl methacrylate. J Am Chem Soc 1954; 76: 6274-80. https://doi.org/10.1021/ja01653a014

[46] Riddick JA, Bunger WB, Sakano T. Organic solvents. 4th ed New York: Wiley; 1986.

[47] Matyjaszewski K, Xia J. Atom transfer radical polymerization. Chem Rev 2001; 101: 2921-90. https://doi.org/10.1021/cr940534g

[48] Matyjaszewski K. Atom transfer radical polymerization (ATRP): Current status and future perspectives. Macromolecules 2012; 45: 4015-39. https://doi.org/10.1021/ma3001719

[49] Christensen JJ, Eatough DJ, Izatt RM. The synthesis and ion binding of synthetic multidentate macrocyclic compounds. Chem Rev 1974; 74: 351-384. https://doi.org/10.1021/cr60289a003

[50] Reusch CF, Cussler EL. Selective membrane transport. AIChE J 1973; 19: 736-41. https://doi.org/10.1002/aic.690190409

[51] Lamb JD, Christensen JJ, Izatt SR, Bedke K, Astin MS, Izatt RM. Effects of salt concentration and anion on the rate of carrier-facilitated transport of metal cations through bulk liquid membranes containing crown ethers. J Am Chem Soc 1980; 102: 3399-403. https://doi.org/10.1021/ja00530a016

[52] Cussler EL, Aris R, Bhown A. On the limits of facilitated diffusion. J Membr Sci 1989; 43: 149-64. https://doi.org/10.1016/S0376-7388(00)85094-2

[53] Noble RD. Analysis of ion transport with fixed site carrier membranes. J Membr Sci 1991; 56: 229-34 https://doi.org/10.1016/S0376-7388(00)80811-X

[54] Igawa M, Tanaka M, Izumi S, Kaneko Y, Yamabe T. Separation of potassium and sodium by liquid membrane, Nippon Kagaku Kaishi 1980; 1980: 135-40.

[55] Moyer BA, Deng Y, Sun Y, Sachleben A. Extraction of cesium nitrate from concentrated sodium nitrate solutions with 21-crown-7 ethers: Selectivity and equilibrium modeling Solvent Extr Ion Exch 1997; 15: 791-810. https://doi.org/10.1080/07366299708934506 
[56] Šísrková $N$, Kolářová $M$, Lučaníková $M$, Bělohradský $M$, Rais $\mathrm{J}$. Liquid-liquid extrtaction of microamounts of ${ }^{137} \mathrm{Cs}$ and ${ }^{85} \mathrm{Sr}$ with chlorinated dicarbollide and crown ethers into mixed dodecanenitrile/n-dodecane nonpolar diluent. Sep Sci Technol 2011; 46: 2174-82. https://doi.org/10.1080/01496395.2011.594849

[57] The National Academic Press. Radiation source use and replacement. Washington, DC: The National Academic Press; 2008.

[58] Kessler G. Sustainable and safe nuclear fission energy technology and safety of fast and thermal nuclear reactors. Berlin: Springer-Verlag; 2012. https://doi.org/10.1007/978-3-642-11990-3

[59] Rosini C, Altemura P, Pini D, Bertucci C, Zullion G, Salvarori $P$. Cinchona alkaloids for preparing new, easily, accessible chiral stationary phases II Resolution of binaphthol derivatives on silica-supported quinine. J Chromatogr A 1985; 348: 79-87.

https://doi.org/10.1016/S0021-9673(01)92441-0

[60] Mandl A, Nicoletti L, Lämmerhofer M, Lindner W. Quinine versus carbamoylated quinine-based chiral anion exchangers: A comparison regarding enantioelectivity for $\mathrm{N}$ - protected amino acids and other chiral acids. J Chromatogr A 1999; 858: 1-11.

https://doi.org/10.1016/S0021-9673(99)00803-1

[61] Franco P, Blanc J, Oberleitner WR, Maier NM, Lindner W, Minguillón C. Enantiomer separation by countercurrent chromatography using chinchona alkaloid derivatives as chiral selectors. Anal. Chem. 2002; 74: 4175-83. https://doi.org/10.1021/ac020209q

[62] Czerwenka C, Lämmerhofer $M$, Maier NM, Rissanen $K$ Lindner W. Direct high-performance liquid chromatographic separation of peptide enantiomers: Study on chiral recognition by systematic evaluation of the influence of structural features of the chiral selectors on enantioselectivity. Anal Chem 2002; 74: 5658-66. https://doi.org/10.1021/ac020372|

[63] Canepari S, Girelli AM, Mattei E, Tosti D. Enantioselective transport of D,L-phenylalanine and D,L-phenylglycine through a bulk liquid membrane containing chichona alkaloid derivatives as chiral selectors. J Braz Chem Soc 2009; 20: 429-36. https://doi.org/10.1590/S0103-50532009000300004

\section{DOI: https://doi.org/10.6000/1929-6037.2017.06.01.2}

(c) 2017 Tsujimoto and Yoshikawa; Licensee Lifescience Global.

This is an open access article licensed under the terms of the Creative Commons Attribution Non-Commercial License (http://creativecommons.org/licenses/by-nc/3.0/) which permits unrestricted, non-commercial use, distribution and reproduction in any medium, provided the work is properly cited. 